\title{
The identity of Albuca caudata Jacq. (Hyacinthaceae) and a description of a new related species: A. bakeri
}

\author{
Mario Martínez-Azorín ${ }^{1,2,3}$, Manuel B. Crespo', Anthony P. Dold², Nigel P. Barker ${ }^{3}$ \\ I CIBIO (Instituto Universitario de la Biodiversidad), Universidad de Alicante, P.O. Box 99, E-03080 Ali- \\ cante, Spain 2 Selmar Schonland Herbarium, Department of Botany, Rhodes University, Grahamstown 6140, \\ South Africa 3 Department of Botany, Rhodes University, Grahamstown, 6140, South Africa
}

Corresponding author: Mario Martinez-Azorin (mmartinez@ua.es)

Academic editor: W. John Kress | Received 24 February 2010 | Accepted 13 June 2010 | Published 27 July 2011

Citation: Martínez-Azorín M, Crespo MB, Dold AP, Barker NP (2011) The identity of Albuca caudata Jacq. (Hyacinthaceae) and a description of a new related species: A. bakeri. PhytoKeys 5: 5-19. doi: 10.3897/phytokeys.5.1166

\begin{abstract}
The name Albuca caudata Jacq. has been widely misunderstood or even ignored since its description in 1791. After studying herbarium specimens and living populations in South Africa, plants fitting Jacquin's concept of that species are found to be widely distributed in the Eastern Cape, mainly in the Albany centre of Endemism. Furthermore, some divergent specimens matching Baker's concept of $A$. caudata are described as a new related species: A. bakeri. Data on typification, morphology, ecology, and distribution are reported for both taxa. Affinities and divergences with other close allies are also discussed.
\end{abstract}

\section{Keywords}

Albuca bakeri sp. nov., Albuca caudata, distribution, taxonomy, typification

\section{Introduction}

The genus Albuca L. is accepted to include about 60 species in recent treatments (cf. Speta 1998; Manning et al. 2002), although up to 131 when considered in a wider sense (Phillips 1951), with over 180 names available in its traditional sense (cf. IPNI 2011). Recent molecular works have however considered the circumscription of Albuca in quite different ways. On the one hand, Manning et al. (2009) enlarged the tradi- 
tional concept of Albuca to include other genera such as Stellarioides Medik., Coilonox Raf., Trimelopter Raf. and Battandiera Maire, reaching a total of 110-180 species, and hence being very heterogeneous in morphology. On the other, Martínez-Azorín et al. (2011) recovered the traditional concept of Albuca on the basis of phylogenetic, morphologic and biogeographic evidences.

Taxa of Albuca in its traditional sense (cf. Martínez-Azorín et al. 2011) are distributed mainly in southern and eastern Africa, with only a few species extending to Ethiopia, Saudi Arabia and north of Chad and Nigeria. The only comprehensive revision of Albuca is that of Baker $(1897,1898)$, who focused on South African and tropical African taxa. Recent accounts (cf. Müller-Doblies 1994, 1995, 2006; Manning and Goldblatt 2009) have greatly increased the knowledge of groups with nodding-flowers, namely A. subg. Albuca and A. subg. Falconera (Salisb.) Baker. However, information on groups with erect-flowers, e.g. A. subg. Mitrotepalum U. Müll.-Doblies (= A. sect. Branciona (Salisb.) J.C. Manning \& Goldblatt), has remained almost unchanged from the late $19^{\text {th }}$ century, and is the focus of our current research (Martínez-Azorín et al. in press $\mathrm{a}, \mathrm{b}$ ). In addition, no identification keys are available for all currently accepted taxa of Albuca, most of which are still poorly known or in need of further studies (cf. Phillips 1926; Dyer 1947). For instance, Albuca caudata Jacq., a plant described from the Cape, has long been misinterpreted or even ignored. The study of herbarium specimens as well as natural populations of wild plants has revealed the existence of different biological entities to which the name $A$. caudata has been applied. In the present contribution, the name $A$. caudata is typified to warrant further usage in the sense it was originally published, and data are also presented to describe a new species to which that name was applied erroneously.

\section{Materials and methods}

Herbarium specimens from the following herbaria were studied: BOL, BNRH, GRA, J, K, KEI, KMG, NBG, NH, NU, PEU, PUC, UFH, WIND (acronyms according to Thiers 2011). Moreover, a detailed morphological study of both taxa was undertaken based on plants from natural populations. Authors of the cited taxa follow IPNI (2011).

\section{Results and discussion}

Albuca caudata was described by Jacquin (1791) and later illustrated (Jacquin 1795) (Fig. 1) after plants collected in "Promontorio bonae Spei", which "Apud nos in caldariis floret Decembri \& Januario". The characters mentioned by Jacquin (1791) are: bulb roundish to ovate; leaves scarce, glabrous, linear-lanceolate, canaliculate, acute, with terete apex; stem weak and inclined; raceme lax, with patent pedicels; tepals white with green bands, the inner tepals with yellowish apices; all six stamens bearing anthers; and style clavate, thick and trigonous. Plants fitting this description are widespread in the Eastern Cape. They are 


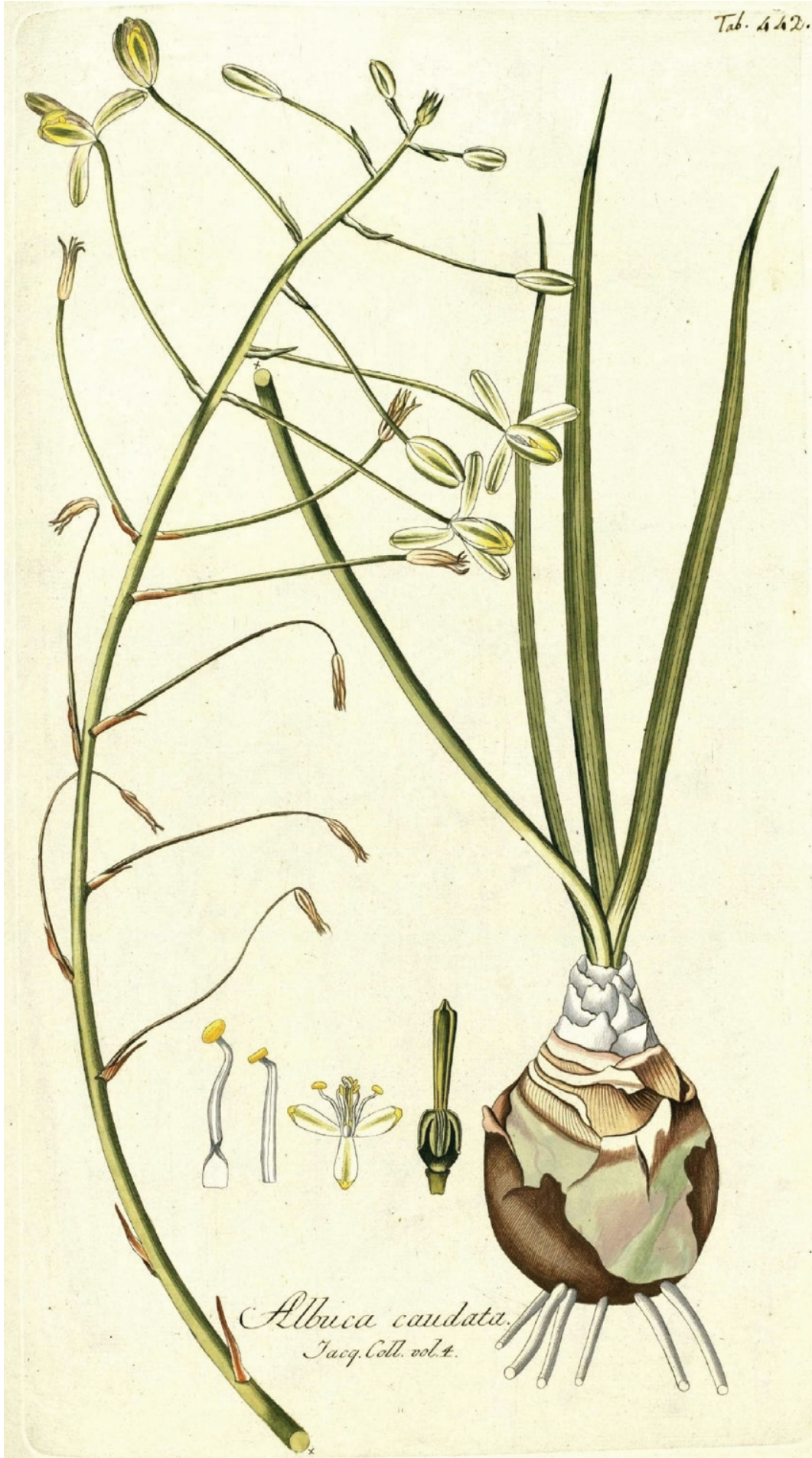

Figure I. Albuca caudata Jacq. from Jacquin, Ic. Pl. Rar. 2(16): 20, t. 442.1795. 
usually easy to recognise by their solitary partially hypogeal bulbs, covered by short, papery, brown to grey scales that reach different heights, and their inclined unilateral racemes with all pedicels erect. However, a wide range in variation of vegetative and reproductive features can be observed, such as morphology of the scales of the bulb neck, leaf length and width, and flower disposition with regard to the inflorescence axis. A number of herbarium specimens labelled $A$. caudata differ significantly from Jacquin's description, but match Baker's concept of that taxon (cf. Baker 1869). These plants are characterized by their hypogeal roundish bulbs with fleshy outer tunics, all of them reaching the top of the bulb and ending into a long epigeal neck surrounded by transversally banded cataphylls. The particular characteristics of those collections, which were illustrated by Baker (1869) (Fig. 2), do not fit any of the known species of $A$. subg. Mitrotepalum. As differences with the typical $A$. caudata are remarkable, segregation at the species rank is here favoured and a new species is described for them. Information on both taxa is provided below.

\section{Albuca caudata Jacq., Collectanea 4: 203 (1791). http://species-id.net/wiki/Albuca_caudata}

Neotype (here designated). Jacquin, Ic. Pl. Rar. 2(16): 20, t. 442 (1795), ex Promontorio bonae Spei. Apud nos in caldariis floret Decembri \& Januario (Fig. 1).

Epitype (here designated). SOUTH AFRICA. Eastern Cape: Alexandria, Addo National Park, 400 feet, 29.X.1954, S.M. Johnson 1077 (GRA).

Description. Evergreen bulbous plants. Bulb mostly solitary and hypogeal, ovoid to oblong, up to $10 \times 6 \mathrm{~cm}$, usually with its wide basal plate elongated into a domed axis where the fleshy scales are attached; tunics fleshy, short and usually not reaching the top of the bulb, imbricate, persistent, papery grey or brownish in the upper part, sometimes with transversal prominent dark ridges, giving a brownish multiscaled appearance to the bulb in outline. Roots fleshy, thick and usually tuberose, white, numerous, up to $200 \times$ $4 \mathrm{~mm}$. Leaves 4-10, disposed in an apical rosette, linear-lanceolate, $15-120 \times 0.5-2 \mathrm{~cm}$, straight up and curving down when old, infolded, canaliculate, persistent, pale bright green to glaucous, glabrous, usually minutely papillate on nerves and margins, with a terete apex evident in young leaves. Inflorescence inclined, unilateral raceme, $11-40 \mathrm{~cm}$ long; peduncle 12-55 cm long; pedicels 3.5-9 cm long at base becoming smaller, up to $0.2-1 \mathrm{~cm}$ long near top, patent and being usually all erect; bracts ovate-lanceolate to triangular, long acuminate, $11-25 \times 5-9 \mathrm{~mm}$, papery white with brownish distant nerves that converge at the tips, much shorter than pedicels in the lower part of the inflorescence. Flowers erect; tepals white with a green median stripe $2-4 \mathrm{~mm}$ wide, sometimes with the tips yellowish; outer tepals oblong, 18-28 × 4-7 mm, apex slightly cucullate; inner tepals ovate, $15-24 \times 4-10 \mathrm{~mm}$, with apex strongly cucullate. Stamens all six bearing fertile anthers; outer anthers 1.5-2.5 mm long; inner anthers 3-4 mm long; outer filaments $10-16 \times 1.5-2 \mathrm{~mm}$, linear lanceolate to narrowly oblong, not pinched down; inner filaments 10-17 $\times 1.5-3 \mathrm{~mm}$, linear oblong, wider and pinched in the lower half. Ovary oblong to obovate, up to $6-8 \times 2-3.5 \mathrm{~mm}$, stipitate, with prominent paraseptal crests that 


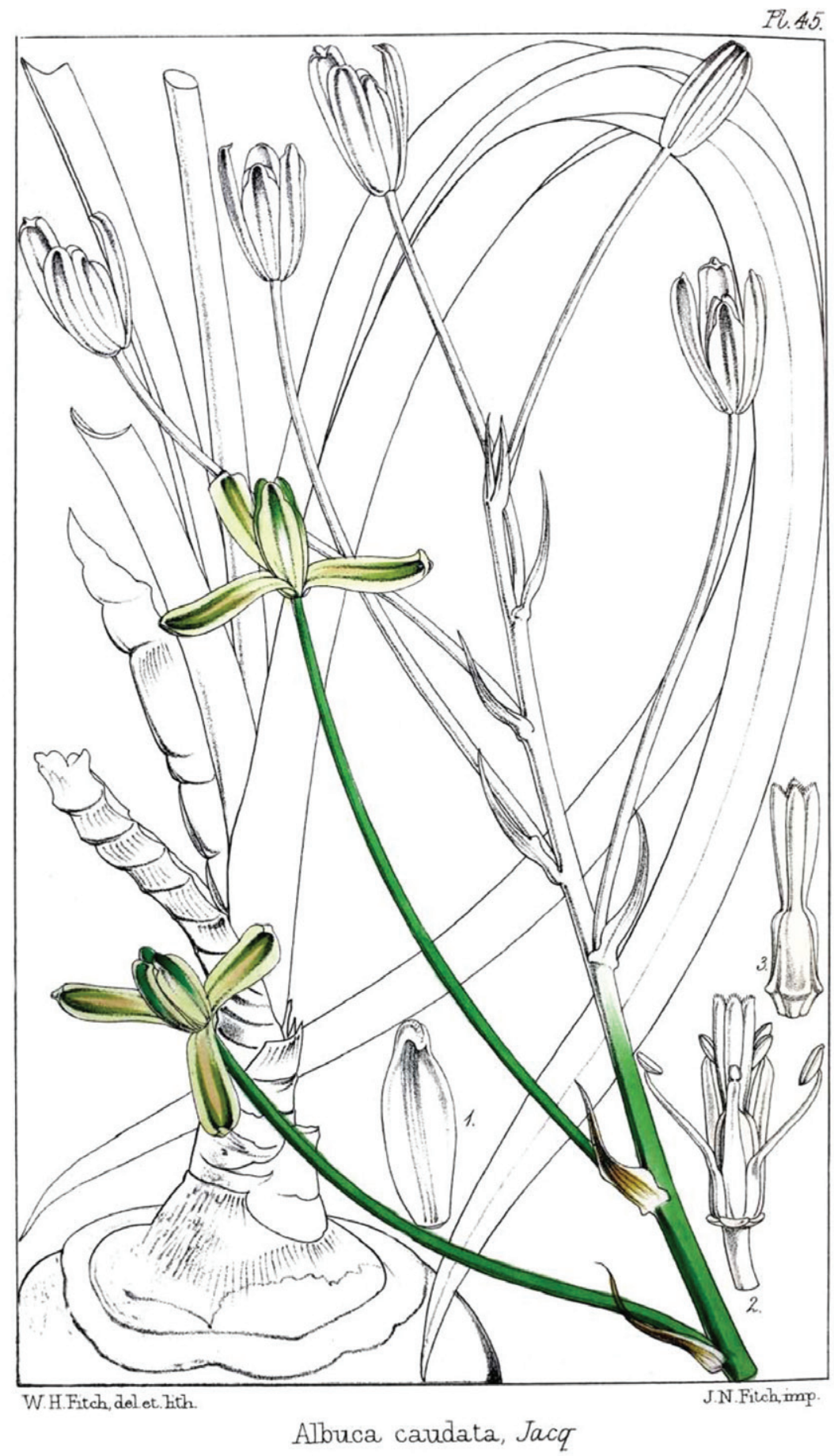

Figure 2. Albuca bakeri Mart.-Azorín \& M.B. Crespo from Baker, Refug. Bot. (Saunders) vol. 1, t. 45. 1869 (as A. caudata). 
are divergent in the lower part and form three prominent ridges; style subobpyramidal or clavate, trigonous, up to 7-10 $\times 2 \mathrm{~mm}$, stigma yellowish green. Capsule ovate, 14-20 $10-14 \mathrm{~mm}$, trigonous to subsphaerical in section, pale-brown when mature; valves splitting in the upper quarter. Seeds flat, c. 5-6 $\times 4-5 \mathrm{~mm}$, dark brown to black, flattened and semidiscoidal, biseriate and horizontally stacked in each locule. (Fig. 3)

Flowering time. September to November; capsules dehiscing at the end of November and December.

Habitat. Plants of $A$. caudata are often associated with bush-clumps, where the inclined inflorescence is supported by woody plants.

Distribution. Currently known from Addo in the west to Grahamstown in the east, below $600 \mathrm{~m}$, with an outlying population as far inland as Somerset East, reaching $900 \mathrm{~m}$ (Fig. 4).

Diagnostic characters. Albuca caudata can be easily identified by its bulb mostly solitary covered by brownish papery scales usually disposed at different heights and bearing long thick tuberose roots, its long and narrow canaliculate or infolded leaves, its inclined raceme, with usually all pedicels patent and erect, giving a unilateral appearance to the inflorescence, and its white erect flowers with a median green stripe (Fig. 3).

Etymology. The specific epithet 'caudata' presumably refers to the rather pointed, tail-like leaves, although Jacquin did not specifically mention it (E.E.A. Gledhill, unpubl. ms. in NBG).

Relationships. The recently described Albuca batteniana Hilliard \& B.L. Burtt (Hilliard and Burtt 1985) shares some morphological characters with A. caudata, such as the inclined scape bearing a horizontally arcuate inflorescence with erect pedicels, and the flower morphology. This species, however, differs in the coriaceous recurved much broader and flattened leaves, the longer tepals (30-42 mm long), and the structure of the bulb, being proliferous, epigeal, and composed by scales truncate at the top, disposed into a long domed axis and ending at different heights, without membranous neck (Table 1).

Observations. A. caudata shows some variability in the colour of the membranous bulb scales, being pale coloured with orange transversal ridges in some inland populations whilst those from the coastal areas are usually brown coloured with darker transversal ridges.

Selected specimens studied. SOUTH AFRICA. Alexandria, 4 miles east of Sandflats, 1000 feet, 17/12/1953, E.E.A. Archibald 5431 (GRA); Eastern Cape, along road in Springs Reserve, north of Uitenhage, 39 m, 21.X.2009, A.B. Low 16732 (GRA); Addo Elephant National Park, in main Botanical Reserve, 20.X.1996, K. Johnson 241 (GRA); Alexandria, Nanaga, opposite Glen Rosa turn-off, 1100 feet, 23.X.1953, E.E.A. Archibald 5315 (GRA); Eastern Cape, Albany, Queen's Road, 10 miles north of Grahamstown, 2000 feet, 05.X.1953, S. Johnson 774 (GRA); Eastern Cape, Albany, a few yards from Archibald 5636, Pluto's Vale, 2000 feet, 22.IX.1954, E.E.A. Archibald 5636 (GRA); Eastern Cape, Grahamstown, c. 5 miles on Cradock road, 626 m, 11.XII.2009, M. Martínez-Azorin \& A.P. Dold 85 (GRA); Eastern Cape, Redhouse, thicket west of village, 6 m, 27.XI.2009, M. Martínez-Azorín, A.P. Dold \& A. Martinez-Soler 45 (GRA). 


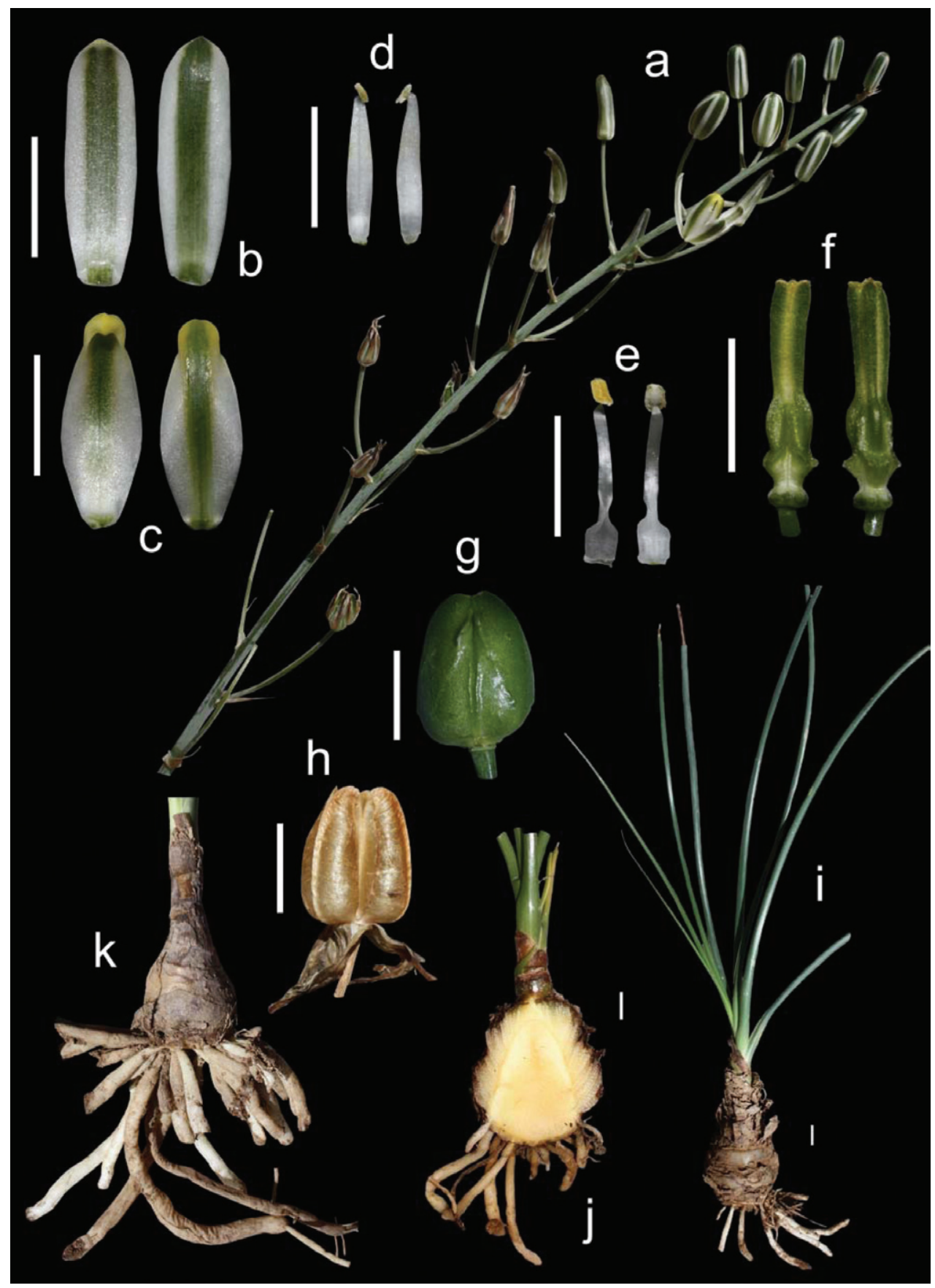

Figure 3. Albuca caudata Jacq. Eastern Cape, Redhouse (M. Martínez-Azorín, A.P. Dold \& A. MartínezSoler 45 GRA) a Inflorescence b Outer tepals c Inner tepals d Outer stamen e Inner stamen f Ovary, lateral views $\mathbf{g}$ Mature capsule $\mathbf{h}$ Dehiscing capsule $\mathbf{i}$ Bulb and leaves $\mathbf{j}$ Bulb in longitudinal section $\mathbf{k}$ Bulb with tuberose roots. Scales $1 \mathrm{~cm}$. 


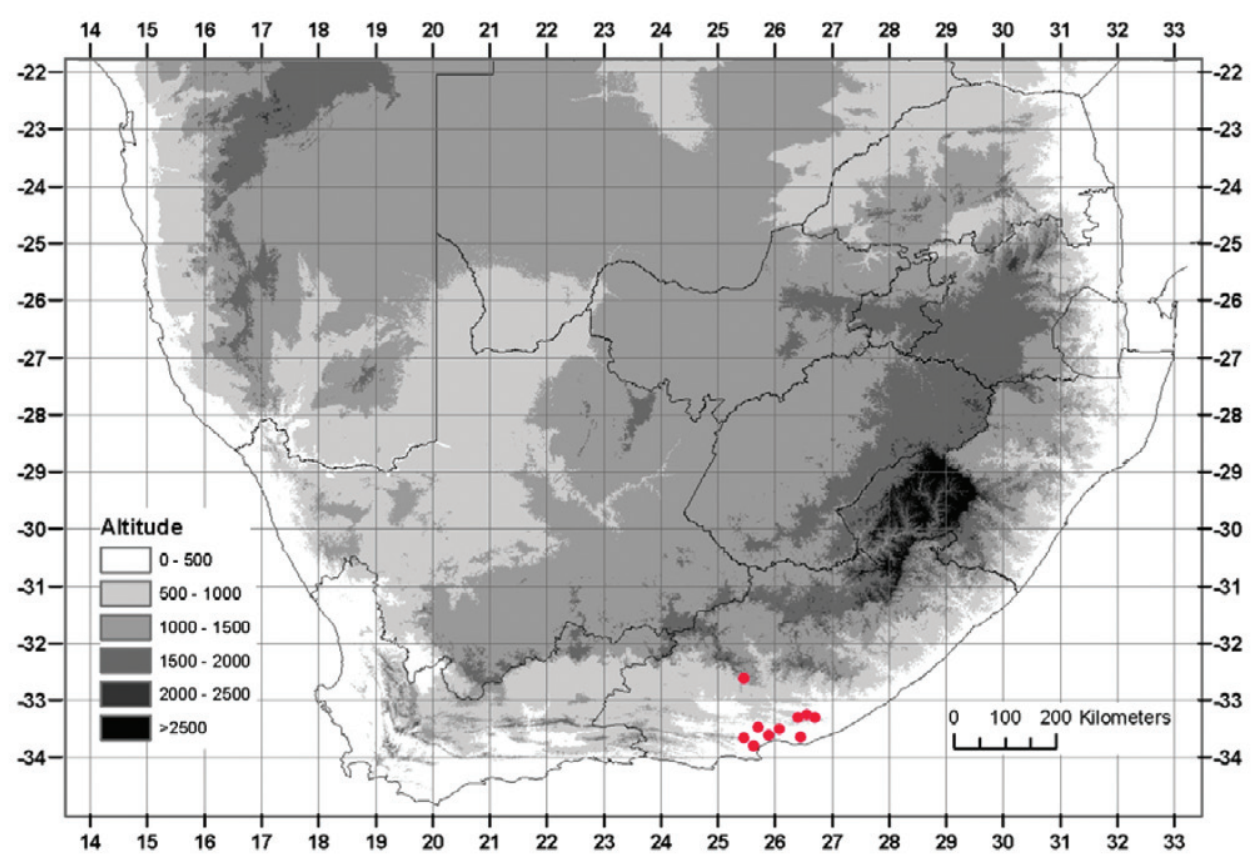

Figure 4. Known distribution of $A$. caudata Jacq.

Albuca bakeri Mart.-Azorín \& M.B. Crespo, sp. nov. urn:Isid:ipni.org:names:77112770-1

http://species-id.net/wiki/Albuca_bakeri

Holotype. SOUTH AFRICA. Eastern Cape: North of Grahamstown, on Cradock Road turn off to Kwandwe, 592 m, 05.IX.2010, 33¹2'39"S, 26 24'07"E, M. Martínez-Azorin \& A. Martinez-Soler 218 (GRA Holo.; ABH, K, NBG, PRE Iso.).

Diagnosis: Species insignis ex Albuca subg. Mitrotepalum characteribus floralibus ad Albucam caudatam accedit, sed valde differt et facile distinguitur bulbo hypogaeo solitario carnoso tunicis omnibus apicem attingentes in collum angustum supra solum desinentes, e basi cataphyllis albido-membranosis manifeste transversaliter fusco-striatis obtectum qui habitum pulchre zebrinum exhibent, insuper racemo subdeltoideo non secundo floribus spiraliter dispositis.

Illustrations: Baker (1869) in Refugium Botanicum, vol. 1, tab. 45 (Fig. 2); Fig. 5.

Description. Evergreen or deciduous bulbous plants. Bulb mostly solitary, occasionally growing in small clumps, hypogeal, ovoid to spherical, $3.2-7 \times 2.5-6.5 \mathrm{~cm}$, with soft outer tunics that are pale and fleshy, ending in a long epigeal neck, up to $10 \times 2 \mathrm{~cm}$, covered with whitish open and sheathing membranous cataphylls bearing transversal sinuous ridges with their lower side pale to dark brown coloured, giving a zebra banding horizontal pattern; tunics fleshy, whitish, all reaching the top of the bulb, concentrically arranged. Roots fleshy, narrow, white, up to $90 \times 2 \mathrm{~mm}$. Leaves 
Table I. Main diagnostic characters among Albuca caudata, A. bakeri and A. batteniana.

\begin{tabular}{l|l|l|l}
\hline & A. caudata & A. bakeri & A. batteniana \\
\hline \multirow{2}{*}{ Bulb } & Mostly solitary & Mostly solitary & Proliferous \\
\cline { 2 - 4 } & Ovoid to oblong & Ovoid to spherical & Narrowly oblong \\
\cline { 2 - 4 } & $\begin{array}{l}\text { Outer tunics membranous, } \\
\text { brown to grey }\end{array}$ & $\begin{array}{l}\text { Outer tunics fleshy, } \\
\text { white to yellow }\end{array}$ & $\begin{array}{l}\text { Outer tunics somewhat } \\
\text { coriaceous, } \\
\text { green to brown }\end{array}$ \\
\cline { 2 - 4 } & Mostly hypogeal & Hypogeal & Mostly epigeal \\
\cline { 2 - 4 } & $\begin{array}{l}\text { Imbricate scales mostly } \\
\text { ending at different heights }\end{array}$ & $\begin{array}{l}\text { All scales reaching the top of } \\
\text { the bulb }\end{array}$ & $\begin{array}{l}\text { Imbricate scales ending at } \\
\text { different heights }\end{array}$ \\
\cline { 2 - 4 } & $\begin{array}{l}\text { Neck absent or short and } \\
\text { thick, covered by brown to } \\
\text { grey membranous scales }\end{array}$ & $\begin{array}{l}\text { Neck long and thin, covered } \\
\text { by transversally banded } \\
\text { sheathing cataphylls }\end{array}$ & Neck usually absent \\
\hline Roots & $\begin{array}{l}\text { Usually numerous, thick and } \\
\text { tuberose }\end{array}$ & Thin and scarce & Thin or slightly thickened \\
\hline Leaves & $\begin{array}{l}\text { Narrow, infolded and } \\
\text { canaliculate }\end{array}$ & $\begin{array}{l}\text { Narrow, infolded and } \\
\text { canaliculate }\end{array}$ & $\begin{array}{l}\text { Wide, flattened and } \\
\text { usually recurved }\end{array}$ \\
\hline Inflorescence & Inclined and secund & Erect and helicoidal & Inclined and secund \\
\hline Outer tepals & $18-28 \mathrm{~mm}$ & $19-23 \mathrm{~mm}$ & $30-42 \mathrm{~mm}$ \\
\hline Seeds & $5-6 \times 4-5 \mathrm{~mm}$ & $4-5 \times 3-4 \mathrm{~mm}$ & $5-7 \times 4-5 \mathrm{~mm}$ \\
\hline
\end{tabular}

2-6, disposed in an apical rosette, linear-lanceolate to oblong, $9-40 \times 0.4-1.3 \mathrm{~cm}$, erect when young and later curving downwards, infolded, canaliculate, persistent or usually deciduous, pale bright green to glaucous, glabrous, usually minutely papillate on nerves and margins, exceptionally with long papillate margins. Inflorescence an erect raceme or subcorymb, 3-15 cm long; peduncle 9-22 cm long; pedicels helicoidally disposed, $3-7.5 \mathrm{~cm}$ long, longer at the base, up to $0.2-0.7 \mathrm{~cm}$ long near top, erect-patent; bracts ovate-lanceolate to triangular, long acuminate, 9-27 × 4-10 mm, papery white with brownish separated nerves that converge at the tips, much shorter than pedicels at least in the lower part of the inflorescence. Flowers erect; tepals white with a green median stripe 2-3 mm wide, sometimes with the tips yellowish; outer tepals lanceolate-oblong, 19-23 × 5-7 mm, with apex slightly cucullate; inner tepals ovate, 13-17 × 6-7 mm, with apex strongly cucullate. Stamens all six bearing fertile anthers; outer anthers $1.5-3$ $\mathrm{mm}$ long, inner anthers 4-6 mm long; outer filaments $10-13.5 \times 1.5-2 \mathrm{~mm}$, linear lanceolate to narrowly oblong, not pinched down; inner filaments 10.5-14.5 $\times 2-3.5$ $\mathrm{mm}$, linear oblong, wider and pinched in the lower half. Ovary oblong to obovate, up to 6-7 $\times 2-3.5 \mathrm{~mm}$, stipitate, with prominent paraseptal crests that are divergent in the lower part and form three prominent ridges; style subobpyramidal or clavate, trigonous, up to 7-11 × 3.5-4.5 mm, stigma yellowish green. Capsule ovate, $14-16 \times 11-12 \mathrm{~mm}$, trigonous to subsphaerical in section, pale-brown when mature; valves splitting in the upper quarter. Seeds flat, c. 4-5 × 3-4 mm, dark brown to black, flattened and semidiscoidal, biseriate and horizontally stacked in each locule. (Fig. 5)

Flowering time. July to September; capsules dehiscing at the end of September and November. 


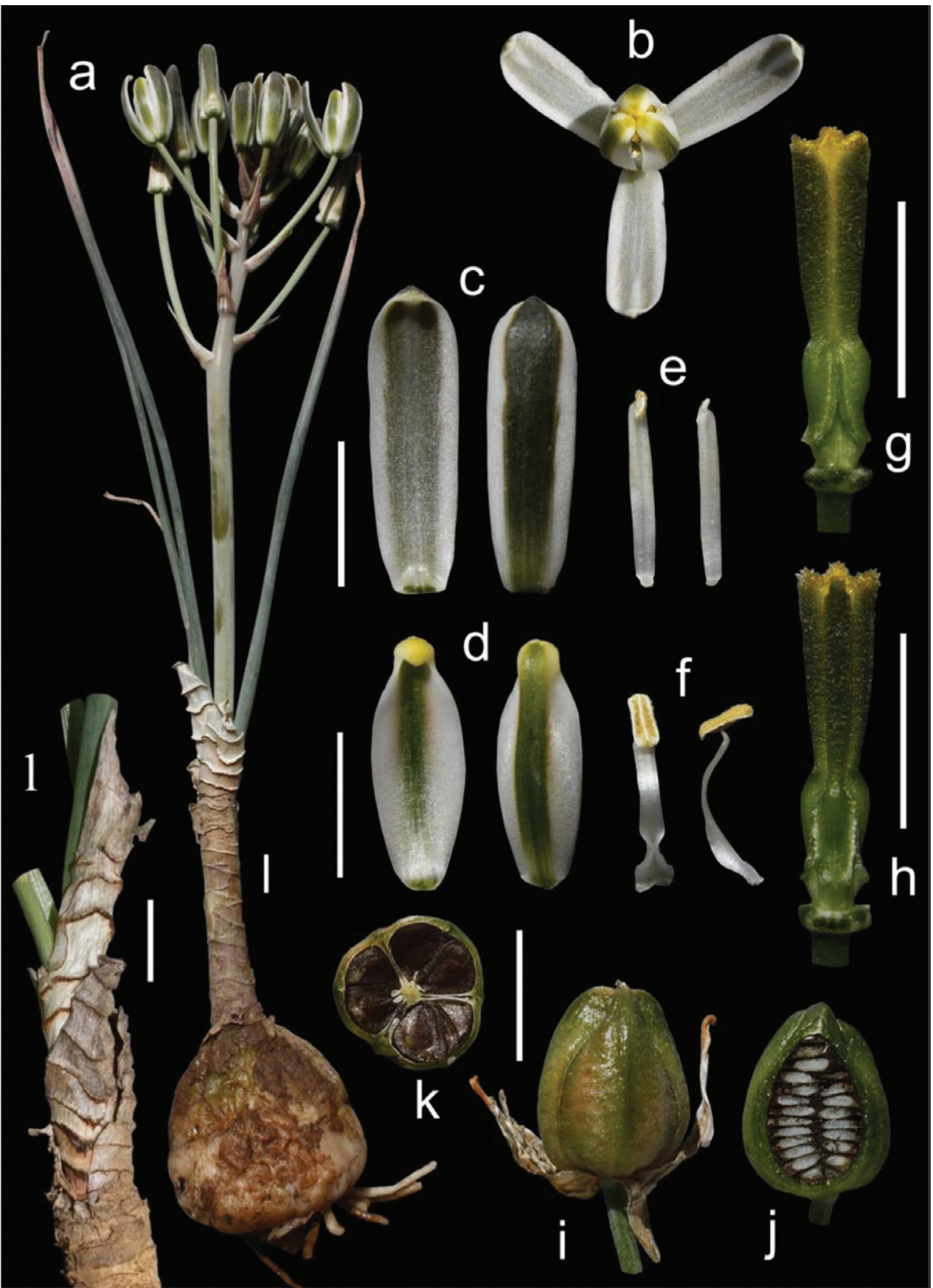

Figure 5. Albuca bakeri Mart.-Azorín \& M.B. Crespo. North of Grahamstown, turn off to Kwandwe (holotype: M. Martínez-Azorin \& A. Martinez-Soler 218 GRA) a Plant b Flower c Outer tepals d Inner tepals e Outer stamen $\mathbf{f}$ Inner stamen $\mathbf{g}-\mathbf{h}$ Ovary, lateral views i Mature capsule $\mathbf{j}$ Capsule, longitudinal section k Capsule, transversal section I Bulb neck with membranous banded cataphylls. Scales $1 \mathrm{~cm}$. 


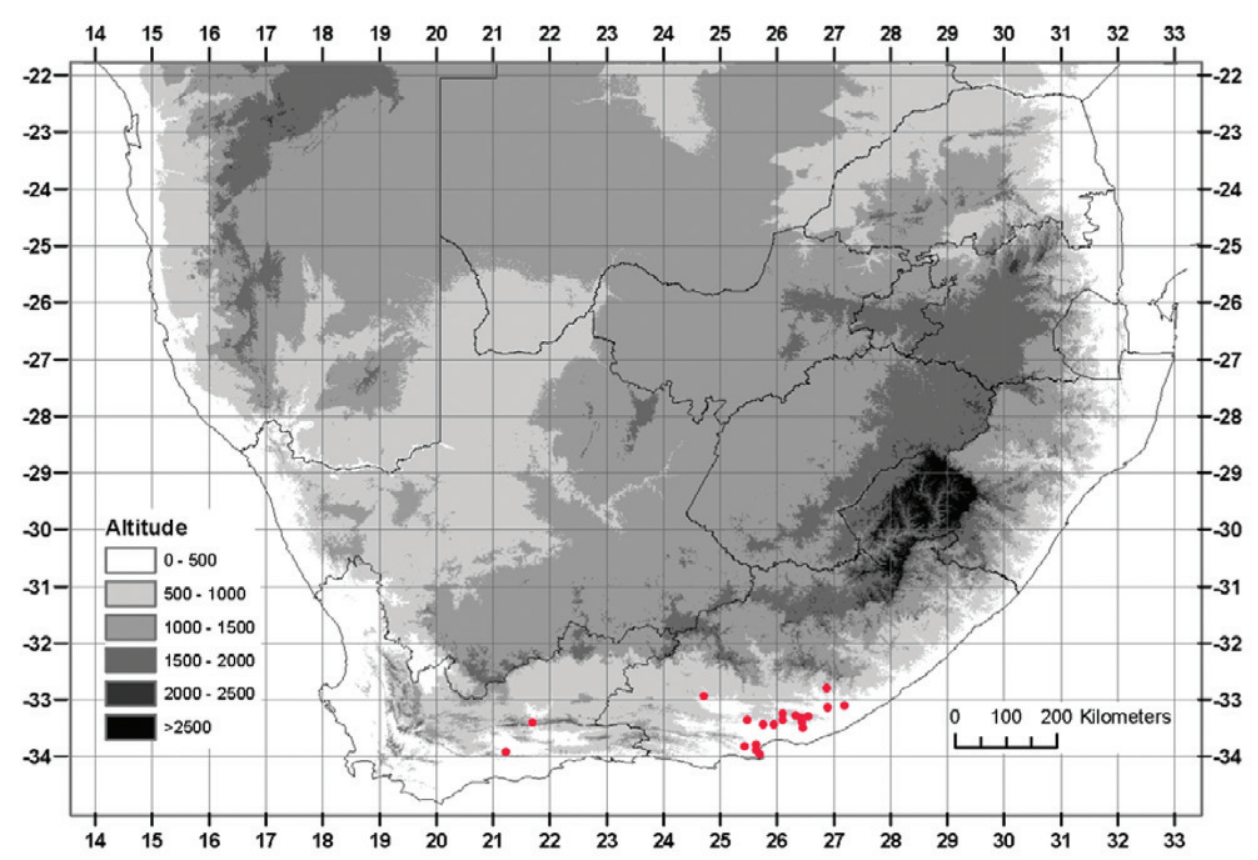

Figure 6. Known distribution of A. bakeri Mart.-Azorín \& M.B. Crespo.

Habitat. Albuca bakeri is found growing singly in dry, stony, open ground at low altitude reaching c. $650 \mathrm{~m}$.

Distribution. from Jansenville to Alice and the Keiskamma river in the Eastern Cape, with two outlying populations near Calitzdorp in the Western Cape karroo (Fig. 6).

Diagnostic characters. Albuca bakeri can be easily identified by its solitary hypogeal fleshy bulb ending in an epigeal neck, covered by whitish transversally banded membranous cataphylls, giving a conspicuous zebra banding pattern (Fig. 5). Moreover, its erect and helicoidal raceme with white and green erect flowers, and the smaller seeds (c. 4-5 × 3-4 mm), separate it from $A$. caudata.

Etymology. Name honouring John Gilbert Baker (1834-1920), a leading expert on monocotyledons, who worked at the Royal Botanic Gardens, Kew, and was the keeper of the herbarium $\mathrm{K}$.

Relationships. No other Albuca with erect flowers have been described with the characteristic long, thin, zebra banded bulb neck of $A$. bakeri. The closest species appears to be $A$. caudata, though the structure of the bulb and inflorescence clearly distinguish them (Table 1).

Observations. The peculiar zebra banded cataphylls of $A$. bakeri are similar to those found in some other groups of Hyacinthaceae. As pointed out by Müller-Doblies and Müller-Doblies (1981), zebrine cataphylls are present in evolutive distant taxa such as Rhadamanthus fasciatus B. Nord., Tenicroa exuviata (Jacq.) Speta (Urgineoideae), several species of Ledebouria Roth (Scilloideae), Coilonox zebrinum (Baker) Speta and some species of Nicipe Raf. [= Ornithogalum sect. Vaginaspasia U. Müll.-Doblies 
\& D. Müll.-Doblies] (Ornithogaloideae). Moreover, Stellarioides arida (Oberm.) Speta and Battandiera stapffi (Schinz) Mart.-Azorín, M.B.Crespo \& Juan show the neck of the bulb covered with membranose transversally banded cathaphylls, indicating that the zebrine cataphylls could have evolved independently in at least five lineages of the Ornithogaloideae (e.g. Albuca, Battandiera, Coilonox, Nicipe and Stellarioides), possibly as a result of convergent evolution in dry climates of southern Africa.

Some morphological variation has been found within $A$. bakeri. Some individuals from Janseville and Port Elizabeth have a slightly setose bulb neck with the characteristic transversally banded membranous cataphylls of this species. Other specimens from Grahamstown and Port Elizabeth showed somewhat proliferous bulbs, resulting in a small clump of plants growing together, and with shorter scales not so markedly banded.

When Baker (1897) described and illustrated his concept of $A$. caudata (Fig. 2), he mentioned: "Bulb two to three inches thick, round or oblong, crowned as in the preceding [A. fastigiata Dryand.] with brown fibres. Leaves about a foot long, four lines broad, more rigid than in the preceding, clasping the stem at the base and more or less concave on the face upwards, and keeled on the back". This description is vague and inaccurate, since the illustration he presented did not show "fibres" at all, and no specific comments on the transversal banding of the upper scales of the bulb were made. However, when Baker reconsidered $A$. caudata in later works, his previous concept was changed to "Bulbus globosus 2-3 poll. crassus viridis apice squamosus" (Baker 1872), or "bulb globose, 2-3 in. diam.; tunics not splitting into fibres at the top" (Baker 1897), or "Bulb globose, 2-3 in. diam." (Baker 1898).

Materials studied. SOUTH AFRICA. Eastern Cape, Alexandria, 11/2 miles east of Paterson, 1000 feet, 24.VIII.1953, E.E.A. Archibald 5972 (GRA); Eastern Cape, Alexandria, south-west end of Zuurkop, Addo National Park, 1000 feet, 23.IX.1953, S.M. Johnson 751 (GRA); Eastern Cape, Albany, 5 miles north of Alicedale, on Riebeck East road, 1500 feet, 21.IX.1954, E.E.A. Archibald 5638 (GRA); Victoria East: Alice, dry stony places on Sandilis Kop on north east side, 08.IX.1934, M.H. Giffen 614 (GRA); Victoria East: Alice, Sandilis Kop western side among grass, 13.IX.1935, M.H. Giffen 618 (GRA); Hillside, Gowie's Kloof, Grahamstown, IX.1947, Hill s.n. (GRA); Grahamstown, West Hill, Pine plantation, VIII.1956, V. van Niekerk s.n. (GRA); Cradock road, Grahamstown, 01.IX.1945, E. Barrat 28 (GRA); In graminosis prope Grahamstown, $M$. Daly \& $M$. Sole 316 (BOL); In graminosis prope Grahamstown, 2000 feet, VIII.1893, Schonland s.n. (NBG); Grahamstown (3326 BC): Ecca Reserve, south near old Queens Road/Quarry, 20.VIII.1992, T. Dold 153 (GRA); Leander Beacon, VIII.1943, L. Miles s.n. (GRA); Port Elizabeth, Summerstrand, grassy roadside, IX-X.1990, H.J. Vanderplank s.n. (GRA); Port Elizabeth (3325CD): $3 \mathrm{~km}$ south of Uitenhage towards van Stadens, 01.IV.1978, P.L. Perry 601 (NBG); Port Elizabeth (3325CB): Kirkwood District, farm Brakleegte, 300 m, 28.VIII.1985, M.T. Hoffman 1064, 1065 (NBG); ibidem, 14.IX.1985, M.T. Hoffman 1002 (NBG); Graaff-Reinet (3224DC): District Janseville, just south of Janseville $(+/-1 \mathrm{~km})$ in municipal-owned land, 11.VIII.1985, M.T. Hoffman 1063 (NBG); 
Ladismith (3321BC): Calitzdorp dam, 22.II.1981, P.L. Perry 1521 (NBG); Ladismith (3321CC): Sopieshoogte, north entrance to Garcia's Pass, Riversdale, 1600 feet, 15.IX.1981, A. Fellingham 149 (NBG); Eastern Cape, Grahamstown, hills above Botanic Garden, 591 m, 14.XI.2009, 3319'04”S, 26³1'15”E, M. Martínez-Azorín \& A. Martínez-Soler 12 (GRA); Eastern Cape, Grahamstown, Burnkraal, 649 m, 24.XI.2009, 3316'40"S, 26²9'41"E, M. Martinez-Azorin \& A.P. Dold 34 (GRA); Eastern Cape, Redhouse, thicket west of village, $6 \mathrm{~m}$, 27.XI.2009, 3350'01"S, 2533'56"E, M. Martinez-Azorín, A.P. Dold \& A. Martinez-Soler 44 (GRA); Eastern Cape, north of Grahamstown, Table Hill farm, 587 m, 11.XII.2009, 33¹5'21"S, 262 $27^{\prime} 17^{\prime \prime E}$, M. Martinez-Azorin \& A.P. Dold 83 (GRA); Eastern Cape, north of Gra-

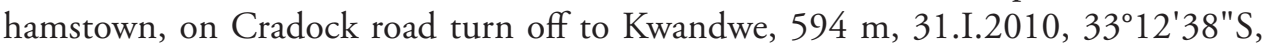
2624'07"E, M. Martínez-Azorin, M.B. Crespo \& A. Martinez-Soler 118 (GRA); Eastern Cape, Quamnyana, between Breakfast Vlei and Commitees Drift, $411 \mathrm{~m}$, 14.VIII.2010, 3306'56"S, 2255'57"E, C. Peter (GRA); ibidem, 27.VIII.2010, M. Martinez-Azorin \& A.P. Dold 207 (GRA); Eastern Cape, Port Elizabeth, Settler's Park, 28 m, 03.IX.2010, 3358'21"S, 2536'09"E, M. Martinez-Azorin \& A.P. Dold 210 (GRA); Eastern Cape, Grahamstown, Sunny side, Hillsview street, 570 m, 07.IX.2010, 3319'08"S, 26³2'00"E, M. Martínez-Azorin \& A. Martinez-Soler 221 (GRA); Eastern Cape, Alicedale, railway cross to Burchell Game Reserve, $288 \mathrm{~m}$,

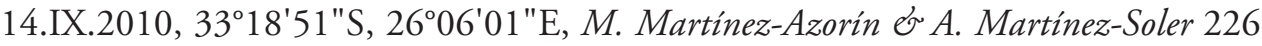
(GRA); Eastern Cape, Alice, Fort Hare University, Sandili's Kop, 582 m, 17.IX.2010, $32^{\circ} 47^{\prime} 02^{\prime \prime}$ S, 2651'38"E, M. Martínez-Azorin \& A. Martinez-Soler 235 (GRA); East-

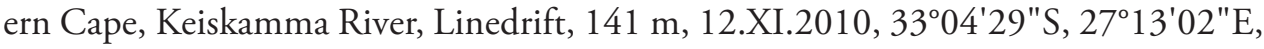
M. Martinez-Azorin, A.P. Dold \& A. Martinez-Soler 525 (GRA).

\section{Acknowledgements}

This work was supported by the Fundación Ramón Areces (Spain). We thank the curators of the herbaria who provided access to specimens examined and the Cacadu Department of Economic Development and Environment Affairs for permission to collect herbarium specimens. Thanks to Cameron McMaster for providing additional images of $A$. batteniana.

\section{References}

Baker JG (1869) Albuca caudata. In: Saunders WW et al. (Eds) Refugium botanicum, Van

Voorst, Paternoster Row, London, 1(2): t. 45. [date on plate and cover 1868]

Baker JG (1872) Revision of the genera and species of Scilleae and Chlorogaleae. Journal of the Linnean Society. Botany 13(68): 209-292.

Baker JG (1897) Albuca. In: Thiselton-Dyer WT et al. (Eds) Flora Capensis, Reeve \& co., London, 6(3): 451-462. 
Baker JG (1898) Albuca. In: Thiselton-Dyer WT et al. (Eds) Flora of Tropical Africa, Reeve \& co., London, 7(3): 528-535.

Dyer RA (1947) Albuca patersoniae. In: Dyer RA (Ed) Flowering Plants of Africa 26: Pl. 1022. Hilliard OM, Burtt BL (1985) 420 Albuca batteniana. Notes on some plants of Southern Africa: XI. Notes from the Royal Botanic Garden, Edinburgh 42(2): 247-249.

IPNI (2011) The International Plant Names Index. http://www.ipni.org

Jacquin NJ (1791) Collectanea ad botanicam, chemiam, et historiam naturalem spectantia, cum figuris, 4: 203. [Albuca caudata]

Jacquin NJ (1795) Icones Plantarum Rariorum 2(16): 20, t. 442. [Albuca caudata]

Manning JC, Goldblatt P, Snijman D (2002) The Color Encyclopedia of Cape Bulbs. Timber Press, Portland, Cambridge.

Manning JC, Goldblatt P (2009) Albuca crispa and A. grandis (Hyacinthaceae: Ornithogaloideae), two new species of subgenus Albuca, the rediscovery of $A$. albucoides (subgenus Osmyne), and the identity of A. reflexa. Bothalia 39(2): 153-163.

Manning JC, Forest F, Dion SD, Fay MF, Goldblatt P (2009) A molecular phylogeny and a revised classification of Ornithogaloideae (Hyacinthaceae) based on an analysis of four plastid DNA regions. Taxon 58(1): 77-107.

Martínez-Azorín M, Crespo MB, Juan A, Fay MF (2011) Molecular phylogenetics of subfamily Ornithogaloideae (Hyacinthaceae) based on nuclear and plastid DNA regions, including a new taxonomic arrangement. Annals of Botany 107: 1-37. doi:10.1093/aob/mcq207

Martínez-Azorín M, Clark VR, Crespo MB, Dold AP, Barker NP (in press a) The rediscovery of Albuca tenuifolia Baker, an orophilous species from the eastern Great Escarpment in South Africa. Nordic Journal of Botany.

Martínez-Azorín M, Crespo MB, Dold AP, Barker NP (in press b) Albuca annulata (Hyacinthaceae), a new species from the Albany Centre of Endemism, South Africa. Nordic Journal of Botany.

Müller-Doblies U (1994) Enumeratio Albucarum (Hyacinthaceae) Austro-Africanarum adhuc cognitarum. 1. Subgenus Albuca. Feddes Repertorium 105: 365-368. doi:10.1002/ fedr. 19941050515

Müller-Doblies U (1995) Enumeratio Albucarum (Hyacinthaceae) Austro-Africanarum adhuc cognitarum. 2. Subgenus Falconera (Salisb.) Baker emend. U.M.-D. 1987. Feddes Repertorium 106: 353-370. doi:10.1002/fedr.19961060506

Müller-Doblies U (2006) Enumeratio Albucarum (Hyacinthaceae) Austro-Africanarum adhuc cognitarum. 3. Additions and additional notes to Albuca subgenus. Falconera and A. subgenus. Albuca. Feddes Repertorium 117: 96-138.

Müller-Doblies U, Müller-Doblies D (1981) Über Verbreitung und Morphologie der Ornithogalum-Arten mit Zebrastreifung (Liliaceae des südlichen Afrika). Willdenowia 11: 45-67.

Phillips EP (1926) Albuca convoluta. In: Dyer RA (Ed) Flowering Plants of Africa 6: Pl. 225.

Phillips EP (1951) The genera of South African flowering plants. Memoirs of the Botanical Survey of South Africa 25.

Speta F (1998) Hyacinthaceae. In: Kubitzki K (Ed) The families and genera of vascular plants, Springer, Berlin, 3: 261-285. 
Thiers B (2011) Index Herbariorum: A global directory of public herbaria and associated staff. New York Botanical Garden's Virtual Herbarium. http://sweetgum.nybg.org/ih/ 